\title{
Pedagoginen hyvinvointi peruskoulun opettajien työssä
}

\author{
TIINA SOINI, JANNE PIETARINEN \& KIRSI PYHÄLTÖ
}

\begin{abstract}
Oppiminen ja hyvinvointi kietoutuvat yhteen. Ne voidaan jopa hahmottaa yksilön kasvu- ja kehitysprosessin eri ulottuvuuksina: riittävä hyvinvointi on tavoitteellisen oppimisen edellytys ja oppiminen mahdollistaa hyvinvointia edesauttavan muutoksen. Kirjoittajat esittävät, että pedagogisen hyvinvoinnin jäsentäminen ilmiönä voisi avata uuden näkökulman opettajien työssä jaksamiseen. Se voi myös auttaa löytämään tapoja tukea opettajien jaksamista. Artikkelin empiirinen osa perustuu perusopetuksessa toimivien opettajien haastatteluihin. Millaisia kuormittumista aiheuttavia ja toisaalta jaksamista tuottavia asioita tutkimuksessa nousi esille?
\end{abstract}

$\mathrm{O}$

petustyö on vaativaa ihmissuhdetyötä, johon sisältyy aina kaksoistavoite: tulee mahdollistaa sisältöjen ja taitojen oppiminen sekä tukea kasvamista ja kehittymistä oppijana ja ihmisenä. Opettajalta tämä vaatii sekä oman erityisalan sisältöjen, menetelmien ja ongelmanratkaisutaitojen hallintaa että ihmisen toiminnan ymmärtämistä ja valmiutta ohjata näitä prosesseja (Rauste-von Wright, von Wright \& Soini 2003). Opetustyö on erityisen haastavaa peruskoulussa, jossa opettajat kohtaavat koko ikäluokan.

Perusopetuksen onnistuminen luo osaltaan pohjaa tulevalle oppimiselle. Peruskoulun merkitystä kasvun ja kehityksen tukemisessa on korostettu myös ajankohtaisissa keskusteluissa lasten ja nuorten hyvinvoinnista. (ks. Thuneberg 2007; Välijärvi, Kupari, Linnakylä, Reinikainen, Sulkunen, Törnroos \& Arffman 2007; Suomen hallituksen lasten, nuorten ja perheiden hyvinvoinnin politiikkaohjelma). Pedagogisessa toiminnassa, tässä tapauksessa peruskoulun kontekstissa, oppimisen ja hyvinvoinnin välistä dynaamista suhdetta voidaan kuvata pedagogisen hyvinvoinnin käsitteellä (Pietarinen, Soini, Pyhältö \& Huusko 2007). Tässä artikkelissa pyrimme avaamaan pedagogisen hyvinvoinnin käsitettä ja prosessia peruskoulussa oppimisen ja hyvinvoinnin tutkimusten näkökulmista.

Koulutus- ja kasvatustehtävän täysipainoinen huomioiminen samanaikaisesti opetustyössä on vaativaa. Opettajat kokevatkin yhä useammin työnkuvansa laajentuneen perinteisestä tietojen ja taitojen opettamisesta kohti oppilaan ja kodin kokonaisvaltaisempaa kohtaamista. Liikkuminen erilaisten kasvattajaroolien välillä saatetaan kokea kuormittavaksi. Opettajien uupumuksesta kertovat tutkimukset antavat viitteitä siitä, ettei koulutodellisuus tarjoa opettajille riittävän mielekästä työskentely-ympäristöä (Pyhältö \& Soini 2007; Hakanen 2005; Syrjäläinen 2002; Huberman \& Vandenberghe 1999). Ne voivat myös kertoa opettajien perus- ja täydennyskoulutuksen ja koulujen todellisuuden välisestä kuilusta. On kuitenkin hyvä ottaa huomioon, että sekä kansallisten että kansainvälisten tutkimusten mukaan pedagoginen toiminta koetaan tyypillisesti hyvin haastavana ja kuormittavana, mutta myös innostavana ja palkitsevana. Opettajien työssä jaksamisen tutkimuksissa mielenkiintoista onkin se, että opettajat ovat ammattiryhmänä samaan aikaan uupuneita ja tyytyväisiä työhönsä. Opettajien arkisen työn ytimessä, pedagogisessa vuorovaikutuksessa, on aineksia sekä työuupumukseen että voimakkaisiin työn mielekkyyden kokemuksiin, työn imuun (Hakanen 2005; Schaufeli \& Bakker 2004).

Perustehtävässä onnistuminen on opettajien työssä kokeman hyvinvoinnin kannalta keskeistä. Koska opettaminen on vahvasti ihmissuhdetyötä, on tärkeää tarkastella opettajien perustehtävää, lapsen ja nuoren kasvun ja oppimisen tukemista, nimenomaan vuorovaikutuksen näkökulmasta. Viime vuosien tutkimusten tulokset viittaa- 
vatkin siihen, ettei koulun eri toimijoiden hyvinvointia ole tarkoituksenmukaista tarkastella toisistaan irrallisina. Esimerkiksi koulun onnistuminen pedagogisessa perustehtävässään riippuu sekä oppilaiden että opettajien hyvinvoinnista ja siitä, millaisen oppimisympäristön koulu molemmille muodostaa. (ks. esim. Vandenberghe \& Huberman 1999; Ryan \& Deci 2000; Savolainen 2001; Pelletier, Legault \& Séguin-Lévesque, 2002; Silins \& Mulford 2002; Tarter \& Hoy 2004; Van Houtte 2006; Karvonen, Vikat \& Rimpelä 2005; Huusko, Pietarinen, Pyhältö \& Soini 2007.) Tutkimukset antavat myös selkeitä viitteitä siitä, että oppiminen ja hyvinvointi kietoutuvat yhteen monin eri tavoin, vaikka kokonaisesityksiä aiheesta ei olekaan (Boekaerts 1993; Krapp 2005). Oppiminen ja hyvinvointi voidaan jopa hahmottaa yksilön kasvu- ja kehitysprosessin eri ulottuvuuksina: yhtäällä riittävä hyvinvointi on tavoitteen suuntaisen oppimisen edellytys ja toisaalta oppiminen mahdollistaa sellaisen toiminnan muutoksen, joka edesauttaa hyvinvointia.

Tässä artikkelissa esitämme, että pedagogisen hyvinvoinnin ilmiön jäsentäminen voisi avata uuden näkökulman opettajien työssä jaksamiseen; jaksamisen ja kuormittumisen prosesseja paremmin tunnistamalla voitaisiin löytää tapoja työssä jaksamista tukevaan työyhteisön kehittämiseen ja täydennyskoulutukseen. Empiirisesti tarkastelemme pedagogisen hyvinvoinnin rakentumista peruskoulun opettajien työssä.

\section{Oppiminen ja hyvinvointi kietoutuvat yhteen}

Perinteisesti hyvinvointia on määritelty jakamalla se fyysiseen, psyykkiseen ja sosiaaliseen hyvinvointiin. Tarkastelu on yleensä ollut lähinnä kielteisten ilmiöiden tutkimusta. Viime vuosina hyvinvointitutkimuksessa on yleistynyt lähestymistapa, joka pyrkii tarkastelemaan hyvinvointia aiempaa kokonaisvaltaisemmin, eri näkökulmia yhdistäen (esim. Jyrkämä 2007; Hakanen 2005; Konu \& Lintonen 2005; Konu, Lintonen \& Autio 2002; Lahelma 1992) ja keskittyen myös myönteisiin ilmiöihin ja ihmisten voimavaroihin (Hakanen 2005; Seligman \& Csikszentmihalyi 2000; Sheldon \& King 2001). Myös stressitutkimuksessa on viime vuosina tapahtunut muutos kohti holistista tarkasteluotetta: yksittäisten jaksamisen ja uupumisen stressitekijöiden ja -reaktioiden kirjaamisen sijaan on stressiä ryhdytty tarkastelemaan ensisijassa monimutkaisina vuorovaikutusprosesseina ja korostamaan erilaisten toiminnan säätelijöiden ja toimijan niistä tekemien tulkintojen dynaamista luonnetta (Kinnunen \& Feldt 2005; Rudolf, Lambert, Clark \& Kurlakowsky 2001; Lazarus \& Lazarus 1994). Tosin suuri osa stressin ja hyvinvoinnin tutkimuksesta keskittyy edelleen pääsääntöisesti yksittäisten tekijöiden, tilanteiden ja reaktioiden sekä niiden välisten vaikutussuhteiden selvittelyyn ja toisaalta hyvin yksilökeskeisiin näkökulmiin (Sonnentag \& Frese 2003).

Vastaavasti oppimisen tutkimus on viime vuosikymmeninä siirtynyt tarkastelemaan oppimisen prosesseja yhä monitasoisemmin ja holistisemmin. Oppimisessa ei ole kyse ainoastaan tiedollisesta muutoksesta vaan myös taidoista, tavoitteista, toiminnasta ja tunteista: oppimisesta keskeisenä inhimillisen kasvun prosessina, jossa prosessin yksilölliset ja yhteisölliset ulottuvuudet ovat erottamattomasti kietoutuneet toisiinsa (esim. Anderson, Reder \& Simon 1997; Cobb \& Bowers 1999; Greeno 1997; Lave \& Wenger 1991; Salomon \& Perkins 1998; Pyhäl-

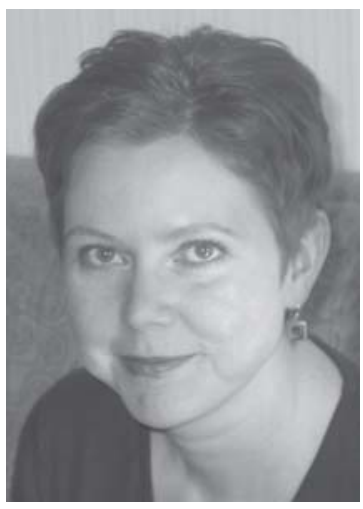

Tiina Soini

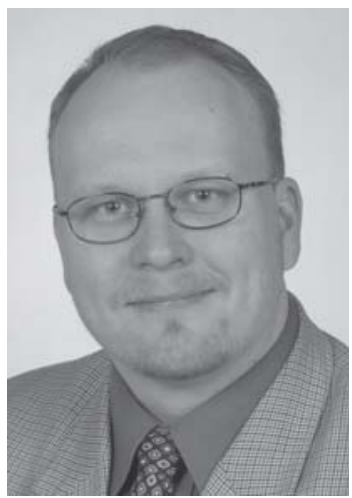

Janne Pietarinen

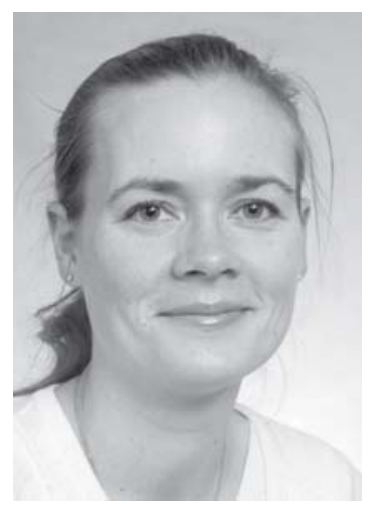

Kirsi Pyhältö tö 2003; Soini 1999; Hakkarainen, Lonka \& Lipponen 2004; Sawyer 2005). Näin ollen koulun pedagogiikan tai oppimisen tarkastelu vain yksittäisen opettajan tai oppilaan tai vaikkapa oppimistulosten tai sisältöjen näkökulmasta ei vielä tuota riittävän analyyttista kuvaa oppimisprosessista. Opettajan kannalta mielekkäiden oppimisympäristöjen rakentaminen edellyttää hyvin monimuotoisten oppimisprosessien ehtojen ja säätelijöiden ymmärtämistä.

Opettajan käsitys itsestään ja suhteestaan mui- 
hin yhteisön jäseniin muodostaa keskeisen viitekehyksen sille, miten hän koulun perustehtävän tulkitsee ja miten se ohjaa hänen pedagogista toimintaansa. Käsityksen itsestä on myös ajateltu olevan melko yleinen ja pysyvä orientaatio, joka heijastuu tunteeseen oman elämän hallinnasta ja ymmärrettävyydestä. Nämä puolestaan edellyttävät, että yksilöllä on mahdollisimman eheä ja johdonmukainen käsitys omista mahdollisuuksistaan vaikuttaa ympäristöön ja myös itseensä. Hyvinvointia edistävä mielekäs vuorovaikutus ympäristön kanssa edellyttää myös merkityksellisyyden kokemusta, joka syntyy tiettyjen perustarpeiden tyydyttymisestä. Näiden ovat tutkimusten valossa ainakin tarve kiinnittyä ympäröiviin sosiaalisiin yhteisöihin, kokea itsenäisyyttä ja vapautta toiminnassaan sekä onnistua tavoitteidensa suuntaisessa toiminnassa. (Antonovsky 1987; 1993; ks. myös Bowen, Richman, Brewster \& Bowen 1998; Torsheim ym. 2001; Pallant \& Lae 2002; Kristersson \& Öhlund 2005; Morrison \& Clift 2005; Deci \& Ryan 2002; Ryan \& Deci 2001.)

Edellä esitetyt ihmisen hyvinvoinnin elementit voisivat hyvin kertoa myös ihmisen tarkoituksenmukaisen oppimisen ehdoista. Silloin kun oppiminen nähdään aktiivisena, sosiaalisena ja intentionaalisena toimintana ja osallistumisena oman ja yhteisön muutosprosessiin, sen keskeisiä onnistumisen ehtoja ovat joustava ja realistinen käsitys itsestä oppijana sekä turvallinen ja hyväntahtoinen sosiaalinen ympäristö, joka mahdollistaa riskien ottamisen. Myös merkitykselliset, realistiset ja omaksi koetut pitkän ja lyhyen aikavälin tavoitteet ovat oppimisen onnistumisen kannalta keskeisiä. Erityisesti sosio-konstruktivistinen oppimisen tutkimus on viime aikoina painottanut kokemusta osallisuudesta (Karila ym. 2006). Tällöin pelkkä eheyden kokemus ei ole oppimisen kannalta riittävä hyvinvointia tuottava elementti, vaan kokeakseen osallisuutta ihmisen on myös koettava itsensä aktiiviseksi toimijaksi suhteessa yhteisön toimintaan (Pyhältö, Pietarinen, Soini \& Huusko 2008).

\section{Pedagoginen hyvinvointi}

Opettajan työn näkökulmasta tarkasteltuna pedagoginen hyvinvointi voidaan nähdä työhyvinvoinnin osa-alueena. Opettajien työhyvinvointi rakentuu monista tekijöistä. Siihen vaikuttavat muun muassa työn määrä, fyysiset olosuhteet, työn jatkuvuus, muutokset ja uudistukset sekä johtamiseen liittyvät tekijät. (Hakanen 2005; Syrjäläinen 2002; Huberman \& Vandenberghe 1999.) Nämä kietoutuvat yhteen ja vaikuttavat toisiinsa. Esimerkiksi koulun johtamiskulttuuri - vaikkapa se, voiko opettaja kokea olevansa mukana päättämässä koulun tavoitteista ja toimintamuodoista voi säädellä merkittävästi sitä, miten hän suhtautuu pedagogiseen uudistamistyöhön tai millaiseen vuorovaikutukseen hän pyrkii muiden opettajien kanssa (esim. Clement \& Vandenberghe 2000). Pedagoginen hyvinvointi voi puskuroida muilla työhyvinvoinnin alueilla koettuja ongelmia, esimerkiksi opettajan onnistumisen kokemukset pedagogisessa toiminnassa voivat tukea yleistä työssä jaksamista silloinkin, kun kiire tai epävarmuus työn jatkumisesta asettavat sille haasteita.

Koulun perustehtävänä on tehdä oppilaille tavoiden suuntainen oppiminen mahdolliseksi. Tähän kuuluu olennaisena osana opettajan jatkuva omassa työssä kehittyminen ja opettajayhteisön pedagoginen kehittämistyö. Pedagoginen hyvinvointi opettajan työhyvinvoinnin osana kietoutuu voimakkaasti tähän perustehtävään. Pedagoginen hyvinvointi ei kuitenkaan koske vain opettajaa ja hänen työhyvinvointiaan, vaan sillä viitataan tavoitteellisessa pedagogisessa prosessissa rakentuvaan hyvin- tai pahoinvointiin, joka puolestaan voimakkaasti säätelee itse pedagogisen prosessin onnistumista. Näin ollen kaikkien koulun toimijoiden riittävä pedagoginen hyvinvointi on koulun tavoitteen suuntaisen oppimisprosessin onnistumisen ehto. Pedagogisen hyvinvoinnin laatua määrittää se, missä määrin vuorovaikutusprosessiin osallistuvat toimijat kokevat eheyttä, merkityksellisyyttä, kuulumisen tunnetta ja aktiivista toimijuutta suhteessa oppimiseen, toiminnan kohteeseen ja pedagogiseen kontekstiin.

Aktiivisen toimijuuden ehdoiksi ymmärrämme tässä yksilön mahdollisuudet oman toimintansa intentionaaliseen ja tulevaisuuteen suuntautuvaan ohjaamiseen ja arviointiin. Se edellyttää minäpystyvyyttä, ymmärrystä toiminnan kohteesta ja omasta suhteestaan siihen sekä osallistumisen valmiuksia, taitoja ja mahdollisuuksia (ks. esim. Jyrkämä 2007; Bandura 2001; Smylie 1999; Soini 1999). Toimijuuden käsitteellä pedagogisen hyvinvoinnin yhteydessä haluamme korostaa eroa pelkän arjesta selviytymisen ja aktiivisen jaksamisen välillä. Hyvinvointi ymmärretään tässä sekä toimintakyvyn ja oman toimijuuden säilymisenä että sen vahvistumisena arjen merkittävissä toiminnan yhteiksissä. Opettajan ammatissa arjen kontekstit ja toi- 
minnan tavoitteet ovat ytimeltään pedagogisia.

Toimijuuteen liittyy myös se, miten toimija hahmottaa toimintansa kohteen ja millainen käsitys hänellä on siitä. Kohteen hahmottamista voidaan tarkastella arvioimalla käsityksen kokonaisvaltaisuutta ja jäsentyneisyyttä (holistinen orientaatio) tai toisin päin toiminnan kohteen kapeutta ja erillisyyttä kokonaisuudesta (atomistinen orientaatio). Koulukontekstissa opettajien jäsentäessä työtodellisuuttaan sekä toimijuuttaan koulun kehittämistyössä heidän käsityksenä toiminnan kohteesta näyttäisivät varioivan merkittävästi atomistisesta holistiseen (Huusko ym. 2007; ks. myös Geyer 1997; Pyhältö ym. 2008).

Pyrkimys eheään toiminnan kohteen hahmottamiseen - ymmärrettävyyteen - on yksilön selviytymiskeino suhteessa ympäristön asettamiin odotuksiin. Tällöin keskeiseksi muodostuu yksilön ja yhteisön mahdollisuudet osallistua yhteisiin merkitysneuvotteluihin, joissa toiminnan kohteelle annetaan merkityksiä, esimerkiksi prosessoidaan opettajayhteisössä koulun kehittämistyön pedagogisia seurauksia (Vanhalakka-Ruoho 2005). Pedagogisen hyvinvoinnin rakentumisessa toimijuus ja osallisuus siis edellyttävät ja rakentavat toisiaan. Osallisuus syntyy jatkuvasta vuorovaikutteisesta prosessista, jossa toimijalla on mahdollisuus vaikuttaa sosiaalisen yhteisönsä käytänteisiin ja myös muokata niitä aktiivisesti. Tällöin myös yksilön toiminta ja käsitys itsestään voi muuttua. Osallisuus on siis toimijuutta suhteessa yhteisöön. Se on myös aina suhteessa toiminnan kohteeseen, kontekstiin ja tavoitteeseen. Yhteisön vuorovaikutusprosessit ja käytänteet voivat sekä mahdollistaa tai estää osallisuutta. Myös koulun arkisia vuorovaikutustilanteita voidaan tarkastella pedagogista hyvinvointia edistävien tai rikkovien kehien rakentumisena.

\section{Pedagogisen hyvinvoinnin rakentuminen opettajan työssä}

Opettajien hyvinvoinnilla on havaittu olevan yhteys koko kouluyhteisön hyvinvointiin. Tämä ei kuitenkaan ole yksiselitteinen syy-seuraussuhde vaan pikemminkin monimutkaisten vuorovaikutusprosessien kokonaisuus. Myös koulun kahden keskeisen toimijaryhmän - oppilaiden ja opettajien - pedagoginen hyvinvointi kietoutuu yhteen monien psyykkisten ja toiminnallisten prosessien kautta. Esimerkiksi oppilaan ja opettajan suhde selittää kouluviihtymistä, (jostain syystä Suomes- sa enemmän kuin muualla), joka osaltaan on yhteydessä kouluhyvinvointiin (Linnakylä 1993). Opettajiin kohdistuvat muutospaineet tai toimintaympäristön muutokset heijastuvat oppilaisiin erilaisten vuorovaikutusprosessien välityksellä. Monissa tutkimuksissa on havaittu, että esimerkiksi opettajiin kohdistuva ulkoinen kontrolli heikentää opettajien sisäistä työmotivaatiota ja saa heidät toimimaan kontrolloivasti suhteessa oppilaisiin, esimerkiksi lisäämään arvioinnin ja kontrollin keinoja. Tällaisessa tilanteessa oppilaat alkavat suosia oppimisessaan suorittamiseen keskittyvää tavoiteorientaatiota, esimerkiksi kehittämään mekanistisia tapoja välttää virheitä. Tämä virheitä välttämään pyrkivä toiminta puolestaan heikentää heidän sisäistä motivaatiotaan ja kuormittaa opettajaa hänen joutuessaan jatkuvasti motivoimaan oppilaitaan. (Gordon, Dembo \& Hocevar, 2003; Ryan \& Deci 2000; 2001; Aunola 2002; Pelletier ym. 2002).

Sekä opettajien että oppilaiden toimintaa luokkahuoneessa säätelevät tekijät, jotka rakentuvat hyvin kokonaisvaltaisesti koulupäivän aikana ja myös koulun ulkopuolella tapahtuneiden asioiden yhteisvaikutuksena. Opettaja toimii usein yksin, luokkahuoneessa ja oppitunnilla pyrkien ratkaisemaan hyvin monitahoisesti, useiden toimintaympäristöjen seurauksena syntyneitä ongelmia. Näiden tilanteiden ratkaiseminen edellyttäisi opettajilta kokonaisvaltaista orientaatiota pedagogiseen prosessiin ja neuvottelua oppilaiden kanssa (Jokinen 2001). Samanaikaisesti kuitenkin toiminnan reunaehdot ja rutinoituneet käytänteet suuntaavat opettajan toimintaa atomististen ratkaisujen suuntaan. Tämä ristiriita on jatkuvasti läsnä opettajan työssä. (Huusko ym. 2007; Helsing 2007; Jahnukainen 2001; Pietarinen 2000; Laine 1997.)

Pedagogista hyvinvointia rakennetaan oppimisprosessissa. Tämä tarkoittaa, että oppimisprosessissa yksilöllä ja yhteisöllä, esimerkiksi yksittäisellä opettajalla ja koko kouluyhteisöllä, on mahdollisuus oppia hyvinvointia tukevia ajattelun ja toiminnan strategioita. Kuormittuminen voidaan puolestaan ymmärtää toimijuuden heikentymisenä, joka voi osittain olla seurausta oppimisesta. Tällöin yksilö tai yhteisö on oppinut toiminnan ja ajattelun strategioita, jotka kaventavat toimijuutta ja maailmankuvaa. Nämä strategiat voivat olla aktiivisia tai passiivisia. Esimerkiksi jälkimmäisessä vetäytyminen, muutosten passiivinen vastustaminen ja itsen ja tai muiden vähättely voivat olla opittuja toimintatapoja. Aktiivisempia selviytymis- 
keinoja voivat olla oman ulkoisen aktiivisuuden, "kierrosten” lisääminen tai muiden toiminnan häiritseminen. Koulussa näitä keinoja käyttävät sekä opettajat että oppilaat.

Edellä kuvatut strategiat voivat olla hyvinkin perusteltuja, esimerkiksi aiempiin negatiivisiin kokemuksiin pohjautuvia, opittuja tapoja suojautua ongelmalliseksi tai kuormittaviksi koettuja tilanteita vastaan. Ne ovat myös usein yritys suojella itseä tilanteessa, jossa omat resurssit ovat vähäiset. Opettaja voi esimerkiksi pyrkiä välttämään tuloksettomiksi koettuja neuvotteluja oppilaan huoltajan kanssa. Yleensä edellä kuvatut strategiat kuitenkin aiheuttavat toiminnan reaktiivisuuden lisääntymistä ja ulkopuolisuuden ja voimattomuuden tunteita, jotka edelleen kuormittavat ja vaikuttavat ympäristöstä tehtyjen havaintojen tulkintoihin kaventavasti. Edelliseen esimerkkiin viitaten, jos oppilaan mahdollisesti ongelmallinen kotitilanne ei tule opettajan tietoon, hän voi tulkita oppilaan oppimisvaikeudet omaksi epäonnistumisekseen tai oppilaan kielteiseksi asennoitumiseksi koulunkäyntiin. Kaventuneet ja kielteiset tulkinnat johtavat edelleen köyhtyviin toimintastrategioihin, joiden ensisijainen tavoite on usein välitön tilanteesta selviytyminen. (Pyhältö 2003.)

Samanaikaisesti riittävän laajan ja holistisen orientaation kanssa myös oman toiminnan rajaaminen on pedagogisen hyvinvoinnin kannalta keskeistä. Emotionaalinen kuormittuminen ja kyynistyminen ovat opettajille (myös useimmille muille ihmissuhdetyöntekijöille) tyypillisiä jaksamista haastavia prosesseja. Niiden taustalla voi olla ristiriita omien idealististen tavoitteiden ja todellisten vaikutusmahdollisuuksien välillä, esimerkiksi opettajien kokemus voimattomuudesta lapsen ja nuoren vaikean elämäntilanteen ratkaisemiseksi. (Kinnunen \& Hätinen 2005; Vandenberghe \& Huberman 1999). Tällöin jaksamista tukee kyllin realistinen käsitys omista mahdollisuuksista vaikuttaa sekä muiden tilanteeseen liittyvien toimijoiden tunnistaminen. Tässä opettajayhteisöillä on joitain nimenomaan niille tyypillisiä haasteita, kuten asiantuntijayhteisön väljäkytkentäisyys tai autonomian ja yhteistoiminnan yhteensovittamisen onnistuminen (Clement \& Vandenberghe, 2000; Weick, 1979).

Kuormittuminen ja pahimmillaan uupuminen on prosessi (ks. esim. Kinnunen \& Hätinen 2005; Bakker ym. 2003; Schaufeli \& Bakker 2004; Demerouti, Bakker, Nachreiner ym. 2001). Se voidaan tietyiltä osin nähdä oppimisprosessina, jossa yksilön maa- ilmankuva (todellisuuden sisäinen representaatio) laajenemisen, rikastumisen ja jäsentymisen sijasta kaventuu, köyhtyy ja pirstaloituu (ks. Rauste-von Wright ym. 2003; Pyhältö 2003; Soini 1999; ). Tällöin esimerkiksi opettajan jatkuva, oman koulun ulkopuolella tapahtuva täydennyskoulutus saattaa muuttua erilaisten pirstaleisten sisältöjen suorittamiseksi ja lisätä kuormittumista sen sijaan, että se tukisi opettajuuden jäsentymistä ja jaksamista tukevaa kehittymistä (ks. myös Meriläinen \& Pietarinen 2007).

\section{Tutkimus ja sen tarkoitus}

Tässä artikkelissa keskitymme tarkastelemaan pedagogista hyvinvointia peruskoulun opettajien näkökulmasta. Edellä olemme kuvanneet opettajien työssään kokeman hyvinvoinnin kahtia jakautuneisuutta, mahdollisuuksia sekä kuormittumiseen että jaksamista tukeviin mielekkyyden kokemuksiin. Tämä muodostaa tutkimuksen empiirisen lähtökohdan. Olemme lähestyneet pedagogista hyvinvointia havainnoimalla kuormittumisen ja jaksamisen kokemuksia opettajan arjessa. Analysoimme sitä, millaiset asiat ja tapahtumat koulussa a) kuormittavat opettajia ja b) mitkä puolestaan tuottavat jaksamista. Tarkastelemme myös sitä, millaisissa konteksteissa pedagoginen hyvinvointi opettajan arjessa ensisijaisesti rakentuu. Lisäksi tarkastelemme sitä, millaiseksi opettajat omaa toimijuuttaan näissä pedagogisen hyvinvoinnin primaarikonteksteissa määrittävät.

\section{Tutkimuskonteksti}

Tässä kuvaamamme tutkimus muodostuu opettajien haastatteluaineistosta, joka on osa laajempaa "Yhtenäisyyttä rakentava peruskoulu" -tutkimushanketta (2005-2009). Hankkeessa on mukana yhteensä 237 koulua ja 87 kuntaa ympäri Suomen. Tapauskouluiksi valittiin tutkimuskouluilta kerätyn rehtorikyselyn (vastausprosentti oli 60) perusteella yhteensä yhdeksän koulua, jotka sijaitsivat eri puolilla Suomea, edustivat rakenteeltaan erilaisia yhtenäisen perusopetuksen toteuttamismuotoja ja olivat yhtenäisen perusopetuksen kehittämistyössään eri vaiheissa. Tapauskouluiksi valittiin kolme alakoulua (vuosiluokat 1-6), kaksi yläkoulua (vuosiluokat 7-9), kolme koko perusopetuksen (1-9) sisältävää koulua sekä yksi yhdistelmäkoulu, jossa annetaan yleisopetusta vuosiluokille 1-6 ja luokkamuotoista erityisopetusta 
koko perusasteella. Yleisopetuksen lisäksi osassa tapauskouluista annetaan sekä valmistavaa opetusta maahanmuuttajille että eriperusteista luokkamuotoista erityisopetusta. Opettajahaastattelut toteutettiin hankkeen kaikissa tapauskoulussa.

\section{Aineiston keruu}

Tapauskouluilta haastateltiin yhteensä 68 perusopetuksessa työskentelevää opettajaa. Opettajahaastattelut toteutettiin puolistrukturoidulla teemahaastattelulla. Haastateltavien opettajien valinta perustui tapauskoulujen kaikilta opettajilta kerättyyn Tulevaisuuden muistelu -aineiston (jatkossa TulMu) analyysiin sekä opettajien taustatietoihin. TulMu-menetelmän tavoitteena on hahmottaa tulevaisuus tyydyttävänä tilana, jossa keskeiset ongelmat on ratkaistu ja josta käsin ongelmaratkaisun prosessia voidaan tarkastella retrospektiivisesti. Tapauskoulujen kaikki opettajat vastasivat TulMu-menetelmällä tehtyyn kyselyyn ja haastateltavien opettajien valinnan ensisijaisena kriteerinä toimi aineistosta analysoidut a) käsitys yhtenäisestä perusopetuksesta koulun kehittämissuuntana ja b) käsitys omasta toimijuudesta tässä kontekstissa. Opettajien kehittämistyössä kokema toimijuus vaihteli aktiivisesta subjektista, toiminnan kohteena, objektina olemisen kokemuksiin. Samoin yhtenäinen perusopetus kehittämisen kohteena nähtiin hyvin erilaisin tavoin, jotka vaihtelivat kapeista atomistisista tulkinnoista monipuolisiin holistisiin käsityksiin (ks. Pyhältö, Pietarinen, Soini \& Huusko 2008). Kustakin tapauskoulusta valittiin haastateltavaksi joukko opettajia, jotka orientoituivat kehittämiseen eri tavoin. Lisäksi haastateltavien opettajien valinnassa hyödynnettiin opettajien TulMu-tehtävän yhteydessä antamia taustatietoja siten, että haastatteluun valittiin sekä aineen-, luokan- ja erityisopettajia että työuransa alussa olevien ja jo pitkän työuran tehneitä opettajia. Tällä menettelyllä pyrittiin varmistamaan myös tältä osin erilaiset taustat omaavien opettajien äänen esiin tuleminen haastatteluissa. (ks. tarkemmin TulMu-menetelmästä Huusko; Pietarinen; Pyhältö \& Soini 2007). Haastattelu sisälsi taustatieto-osion ja opettajan rooliin ja asiantuntijuuteen, kouluyhteisöön ja sen muutokseen sekä oppilaisiin liittyvät haastatteluteema-alueet. Tyypillisesti yksittäinen haastattelu kesti noin tunnin. Kaikki opettajahaastattelut nauhoitettiin ja litteroitiin kokonaisuudessaan.

\section{Aineiston analyysi}

Aineiston analyysi toteutettiin induktiivis-deduktiivisena sisällön analyysinä. Analyysin ensimmäisessä vaiheessa opettajahaastatteluista poimittiin systemaattisesti omiksi hermeneuttisiksi yksiköikseen kaikki ne tekstisegmentit, joissa opettajat kuvasivat omaan työhönsä kytkeytyviä jaksamista tai kuormittumista tuottavia prosesseja tai tekijöitä. Analyysin toisessa vaiheessa nämä pedagogisen hyvinvoinnin rakentumisesta kertovat tekstisegmentit koodattiin kahteen pääluokkaan: (a) jaksaminen ja (b) kuormittuminen._Luokkien muodostamisen kriteerinä toimivat tilanteiden seuraukset toisin sanoen se, kuvasiko opettaja tilanteen itselleen kuormittavaksi vai jaksamista tukevaksi. Analyysin viimeisessä vaiheessa pääluokat luokiteltiin vielä aineistolähtöisesti kolmeen primaarikontekstiluokkaan sen perusteella, mihin tilanteeseen opettajan kuvaama tapahtuma sijoittui. Laadullisen aineiston analyysi toteutettiin ATLAS-ti ohjelman avulla. Koodaukset laadullisesta aineistosta teki koko tutkimusryhmä, samoin se validoi koodauksiin pohjautuvat sisällölliset tulkinnat kunkin analyysivaiheen päätteeksi (tutkijatriangulaatio) (ks. myös Yin 1994, 91-92; Miles \& Huberman 1994, 278-280; Huusko 1999 147-148).

\section{Opettajien jaksamista ja kuormittumista peruskoulussa}

\section{$\mathrm{O}$} pettajat kuvasivat pedagogisen hyvinvoinnin rakentumista, yhtäällä jaksamista ja toisaalta kuormittumista monipuolisesti. He myös tunnistivat monia kuormittumiseen ja jaksamiseen johtavia ydinprosesseja ja säätelijöitä. Opettajien kuvaukset jaksamiseen ja kuormittumiseen liittyvistä prosessista ja tapahtumista sijoittuivat kolmeen pääkontekstiin: (1) opettaja-oppilas väliseen, (2) opettajayhteisön sisäiseen ja (3) opettaja-huoltaja väliseen vuorovaikutukseen (ks. myös taulukko 1.). Nämä primaarikontekstit ovat kaikki vuorovaikutuksellisia ja niiden toimijat (oppilaat, muut opettajat ja huoltajat) muodostavat myös opettajan työn merkittävimmät sosiaaliset viiteryhmät. Se, kokiko opettaja eri kontekstien vuorovaikutukseen kytkeytyvän tapahtuman työn kuormittavuutta lisääväksi vai työssä jaksamista edesauttavaksi, oli sidoksissa opettajan käyttämiin toimintastrategioihin ja valmiuteen jäsentää oman toimintansa pedagogisia seurauksia. 
Taulukko 1: Opettajan pedagogisen hyvinvoinnin rakentuminen primaarikonteksteittain

\begin{tabular}{|llll|}
\hline Primaarikonteksti & Jaksaminen (f) & Kuormittuminen (f) & Yhteensä (f) \\
Opettaja-oppilas & 105 & 82 & 187 \\
Opettajayhteisö & 107 & 41 & 148 \\
Opettaja-huoltaja & 13 & 35 & 48 \\
Yhteensä (f) & 225 & 158 & \\
\hline
\end{tabular}

\section{Opettaja-oppilasvuorovaikutus}

Kuten yllä olevasta taulukosta 1. käy ilmi, suurin osa opettajan työn kuormittumisen ja jaksamisen kuvauksista liittyi opettaja-oppilasvuorovaikutukseen. Tämä viittaa siihen, että yleisimmin pedagogisen hyvinvoinnin rakentumisen kontekstin opettajan työssä muodosti opettaja-oppilasvuorovaikutus. Erityisen merkittäviksi, opettajien työssä kuormittumista ja jaksamista tuottaviksi tilanteiksi, määrittyivät ongelmatilanteet ja niiden ratkaisut. Ongelmat liittyivät yleensä yksittäisen oppilaan tai oppilasryhmän kanssa kohdattuihin pedagogisesti vaativiin tilanteisiin ja siihen, miten opettaja oli onnistunut ongelman ratkaisemaan. Keskeistä ratkaisustrategian valinnassa oli se, kuinka hän on kyennyt analysoimaan kyseistä pedagogista kohtaamista tai tilannetta jaettuna, opettajaoppilasvuorovaikutteisena oppimisprosessin osana.

”...Että se täytyy jotenki se oppilas saaha niinko hanskaan sillä tavalla, että sinulla täytyy olla kontakti, jonkin näkönen kontakti siihen, semmonen plus-kontakti. Jos sul on paljon negatiivista kontaktia siihen lapseen, että sie koko ajan sitä jou'ut niinkö torumaan ja muistuttammaan ja, ja tuota, ja samasta asiasta jankkaamaan, että taas sinä oot myöhässä, taas sulla on hommat tekemättä, niin kaiken sen negatiivisen torumisen jälkeen sulla täytyy olla sieltä se iso plussa repiä jostakin. Ja jos sulla ei sitä ole, niin se lapsi kyllä menehtyy sitte siihen, että. (...) Ettei sille lapselle jää semmonen, semmonen mieli, että, että tuo opettaja ei ole välittäny hänestä riittävästi. (...) Ko ajattelee sitä ommaa tilannetta, että onko mulla nyt tuo päässy pikkasen liian heleposti sormien läpi, niin kyllä, kyllä joskus on semmonen tilanne, että se jää niinkö vaivaamaan, mutta sitte taas astuu sitten se myöskin se työnohjauksellinen näkökulma, että hetki, että sinähän et ihan kaikkea pysty tekemään.” ”...viime tunnilla, ni huomasin, että yks tyttö oli, joka ei kotona kykene lukemaa esimerkiks lukuläksyä ollenkkaa, tai hänt ei tueta kotona, et jouttuu tässä ammatissa toimimaan niin monena, että on vähä sitte äitinä ja isänä ja vaikka minä välillä. Ni esimerkiks sellanen tilanne, että hän oli lukuläksyn lukenu erinomasen hyvin. Ja mie oon kysyny jo monta kerttaa sitä, että "luitko lukuläksyn?". Ja joo, hän luki, että "luin ääneen kotona”. Et hän on ite itsenäisesti sen hoitanu sen homman ilman, että siinä on kukaan häntä tukenu kotona, joka on iso askel. Siis ihan älyttömän iso askel tämmöseltä alisuoriutujalta, joka hän niinku on. Ni äsken tuossa ni luettii sitte ääneen niitä, juttuja, ja huomasin heti, että nyt on muuten luettu ja nyt muuten ossaat. (T: Työ on tehty.) Työ on tehty, ni äkkiä välitön palaute sille tytölle, "että XXX, sie oot, nyt kuule kuunnelkkaa muutki, että miten hienosti sie oot lukenu tän lukuläksyn, että nyt sen kyllä kuulee”. Ja se hymy, joka tuli sieltä ja se hyvä olo, että. (...) Ni ehkä tuo nyt voi olla semmonen, tämmönen pieni tilanne. Mut niitä mie niinku yritän koota joka päivä, (T: Joo.) koska mie jaksan itekki sillon paremmin, kun niinku niitä yritää koota sieltä.”

Opettajat jäsensivät ammatillista onnistumista yleensä oppilaiden kanssa saavutettujen tai saavuttamatta jääneiden pedagogisten tavoitteiden kautta. Ratkaistessaan pedagogisesti haastavia tilanteita opettajat kokivat toimivansa itselle merkityksellisellä, oman työn ydinalueella. Tämä näkyi opettajien aktiivisina pyrkimyksinä ymmärtää, jäsentää ja ratkaista ongelmallisia tilanteita. Se kuvastui myös tilanteiden ja tapahtumien voimakkaan emotionaalisina sävyinä: esimerkiksi jatkuvana tasapainoiluna oman riittämättömyyden tunteiden ja jaksamisen kanssa erityisesti silloin, kun opettaja koki olevansa voimaton kohdatessaan oppilaita, jotka voivat pahoin ja oireilevat elämäntilanteeseensa liittyvien seikkojen vuoksi.

Jaksamisen kuvauksille tyypillistä oli analyyt- 
tinen, ennakoiva ja holistinen ongelmanratkaisu ja mahdollisten tukitarpeiden analysoiminen sekä voimakas kokemus oman työnsä peräsimessä olemisesta. Tällaiselle lähestymistavalle tyypillistä oli myös se, että opettaja pyrki hahmottamaan koulun arkea kokonaisvaltaisesti oppilaiden (toimijuuden) näkökulmasta. Tällöin opettaja hyödynsi ongelmanratkaisussa koulupäivän kokonaisuutta aina oppitunneista välitunteihin ja edelleen koulun ulkopuolisiin resursseihin ja oppimisympäristöihin. Pedagogisesti haastavia tilanteita ratkaistessaan opettajat myös aktiivisesti määrittivät oman työnsä rajoja.

Opettajat tiedostivat, että työn kuormittavuustekijöinä näyttäytyviä, oppilaiden koulussa tai sen ulkopuolella kohtaamia ongelmia ei voida täysin poistaa koulun arjesta. Pikemminkin opettajien kuormittumisen puskuroinnissa oli kyse halusta löytää yhä toimivampia ja mielekkäämpiä toimintamalleja käsitellä ongelmia. Työn kuormittavuutta lisääviksi koettiin puolestaan tilanteet, joissa opettaja koki omat toimintamahdollisuutensa ja keinot tilanteen ratkaisemiseksi syystä tai toisesta vähäisiksi.

”...Mut nyt vanhempana vähä jo niinku varoo. Sit tietenki kaikki just nää, ku ei oikein tiiä, että miten suhtautuu, ku sanotaan nää ulkopuolelta tulevat paineet. Et oppilailla on sen verran enemmän nykyään näitä ongelmia, jotka on sellasii, jotka ei, en mie välttämättä osaa niit käsitellä. Enkä mie tiiä miten mie toimisin niissä, miten mie hoitasin eteenpäin...”

Oppilastyöhön liittyen opettajat tunnistivat ja toivat esiin tarpeen mielekkäiden jaksamista tukevien toimintastrategioiden kehittämiselle. Erityisen tarpeelliseksi ja toisaalta haastavaksi nähtiin sellaisten ammatillisten toimintamallien kehittäminen, jotka mahdollistavat kestävän ja pitkäjänteisen monitahoisten ja -tasoisten ongelmien ratkaisemisen yhdessä oppilaiden kanssa. Aiempaa mielekkäämpien toimintamallien kehittäminen nähtiin samalla keinoksi hallita koulun arjen ja opettajan työn kaaosta, epävarmuutta ja hektisyyttä - ja näin edistää työssä jaksamista.

\section{Opettajayhteisön vuorovaikutus}

Opettajayhteisö muodosti toiseksi yleisimmän pedagogisen hyvinvoinnin primaarikontekstin (ks. Taulukko 1.). Toisin sanoen opettajat määrittivät oman työnsä kannalta opettajayhteisön toiseksi merkittävimmäksi kuormittumista ja jaksamista sääteleväksi tekijäksi. Huomattavaa on, että selkeästi suurin osa maininnoista kuvasi jaksamista. Työssä jaksamista edistävinä tekijöinä opettajat kuvasivat työyhteisön positiivista ilmapiiriä, kannustavaa johtajuutta ja kollegoiden tukea. Työn kuormittavuutta lisäsivät puolestaan huono ilmapiiri, vastavuoroisen ammatillisen arvostuksen puute ja johtajuusongelmat.

”...T: Mistä tulee tukea työhön tällä hetkellä? H: No... Tietenki se on kiva, että tässä on kiva tää porukka ihan tässä, mut että. Nyt on nää, tosiaan nää meijän yhteistyöpalavarit, perjantaipalaverit ja muut, ku me ollaan saatu ite niihin vaikuttaa. Niin ne on tuonu semmosta pohjaa, että tuntuu tosiaan, että on niinku älyllisempi kontakti. Et niinku miettii pedagogisia juttuja paljo enemmän, enemmän sillä tavalla ja viittii funtsia niitä. Ja sitte voi keskustella jonkun kanssa. Ku eihä, eihä, täähä on niinku lähtökohta, onhan näitä opettajanhuoneita, missä kaikki hulinalla äkkiä tekee niinku ja muut menee omille ja saa just omat asiasa hoidettua. Mut että monet pedagogiset asiat on just semmosia, että niitä... pitäs aikuisten kanssa päästä juttelemaa, keskustelem, funtsimaa."

”... Että onks tää nyt ihan oikeesti tää, tää miun juttu, että jaksanko mie vetää tämmöstä systeemiä perässä. Ja niinku tää talvi oikeestaan ollu niin raskas sillä tavalla, että niinku se, on ruvennu miettimmään, että voisko niin sanotusti helpommallakkii päästä. (T: Mm.) Ja tuo koko ajan vaihtunu työkaveri ja ei oo päteviä ja sit jouvvut vetämää koko näin isoo kouluu niin tuota se on sillä tavalla, se on ehkä muuttanu sitä. Että pitäskö siirtyy alakouluun, että se on tietynlainen tullu semmonen opettajuuden miettiminen. T: Oot sie ajatellu mikä sen tekee niin raskaaks tän yläkoulun puolen ja tää tehtävä? H: No niinku mie varmaan siinä vastasinki siinä, että kun tuota yhteistyö aineenopettajien kanssa ja vanhempien ja nuorten kanssa, et silleen niinku et tietynlainen. Meil on, mul on erilainen näkemys ku aineenopettajilla. Ja sit semmonen tiiäkkö kelle sie, yhelle kumarrat, sie toiselle pyllistät, että tuota. Et se semmonen tietynlainen. Et molemminpuolinen arvostus puuttuu. Et se on niinku 
se on se raskas. Et totta kai on semmosia, joitten kansa tulee tosi hyvin toimeen, mutta sitte on taas, että jotka niinku tuo, vettä niskaan tulee kyllä, että tuutin täyveltä, että ku ei. Ei arvosteta ja sit semmonen niinku, että kuitenki pitäs antaa, mutta ei niinku ihan sama."

Opettaja kokivat opettajayhteisön tuen merkityksen suureksi työssä jaksamisen tukena. Opettajat esimerkiksi arvostivat mahdollisuutta keskustella omassa työssä koetuista ongelmista opettajayhteisössä ja korostivat työyhteisön emotionaalista tukea. He eivät kuitenkaan tunnistaneet itseään ammatillisesti vuorovaikutteisen yhteisön aktiivisiksi rakentajiksi. Vain harvat opettajat analysoivat työilmapiiriin vaikuttavia tekijöitä tai pyrkivät itse aktiivisesti ja tavoitteellisesti kehittämään työyhteisöään toivomaansa suuntaan, vaan he suhtautuivat siihen pikemminkin annettuna työn reunaehtona.

Kiinnostavaa on, että opettajat orientoituivat työyhteisön kehittämiseen passiivisesti samalla, kun he toivat esiin tarpeen kehittää yhä holistisempaa työotetta pedagogisesti haastavien tilanteiden ratkaisemiseen oppilaiden kanssa (ks. myös Pyhältö, Pietarinen, Soini \& Huusko 2008). Passiivinen orientoituminen opettajayhteisön kehittämiseen ja epäanalyyttinen ote antavat viitteitä siitä, etteivät opettajat hahmota ammatillista yhteisöä samalla tavalla työnsä ydinalueeksi kuin työskentelyä oppilaan kanssa.

Pedagogisen hyvinvoinnin rakentumisen kannalta kiinnostavaa on myös se, että samalla kun opettajayhteisö muodosti suurimman jaksamista tukevan primaarikontekstiluokan, määriteltiin se vähäiseksi kuormittavuustekijäksi oppilastyöhön verrattuna. Tämä saattaa johtua osaltaan siitä, että työyhteisön tuen merkitys korostuu, kun opettaja kohtaa ongelmia muissa primaarikonteksteissa. Monesti opettajat kuvasivatkin emotionaalista tukea ja yleistä hyvää henkeä jaksamista tukevina tekijöinä.

Työyhteisön vähäinen merkitys kuormittavuustekijänä saattaa johtua puolestaan siitä, että opettajat kokevat työnsä siinä määrin itsenäiseksi, etteivät mahdolliset työyhteisön ongelmat muodostu kovin kuormittavaksi, jos opettaja on muuten tyytyväinen työhönsä ja kokee onnistuvansa erityisesti työssään oppilaiden kanssa.

\section{Opettaja-huoltajavuorovaikutus}

Pedagogisen hyvinvoinnin pienimmän primaarikontekstiluokan muodosti opettajan ja huoltajan välinen vuorovaikutus. Tähän primaarikontekstiin sijoittuville kuvauksille tyypillistä oli, että opettajan ja huoltajien kohtaamisen motiivina ja sisältönä olivat oppilaan koulunkäyntiin liittyvät asiat.

”...oppilaiden koulunkäyntiin, sosiaalisiin suhteisiin liittyviä juttuja vähän tapauksesta riippuen. Sitte tuota niin huoltajan kans tota nii sähläämiseen liittyviä ongelmia. Eli tota huoltajat on tullu yhä röyhkeemmiks. Ne kokee koulun niinku niin jokskii supermarketiks, jossa opettajat ja henkilökunta on niinku kaupan kassoja, jolle voi valittaa huonosta palvelusta ja ne niinku vaatii palvelua. Että ne ei enää miellä, että oppilaal on niinku oppivelvollisuus, niinku peruskoulussa. Ne pyrkii niinku sanelemaan ja pomottamaan...”

”...yks [oppilas] koki olevansa kiusattu. Ja sitte tota juteltii sen kiusattu ja kiusaaja ja mä olin siinä mukana ja siitä ihan avoimesti siitä juttelin, koska mä oon sitä mieltä, että ne kaikki täytyy ottaa avoimesti eikä sillai, että ei saa puhua mitään, että muuten tulee enemmän vaan kiusaamista. Ja sitte siinä, kun niitä juttelee oikein avoimesti, niin siinä tulee se empatia kaikkia kohtaan. Ja sit erityisesti siinä, kun me seurattiin sitä kiusaamisjuttua, et me tavattiin viikottain. Mun mielestä meil oli tosi semmonen, kaikki ymmärsi toisiansa. Oppilaat ymmärsi minua, että miks meijän piti tavata ja sitten ymmärsivät toisiansa ne oppilaat... Se mulla, se oli semmonen pidempi juttu, että mitä meillä oli varmaan useampia viikkoja. Ja sit se tietty tuntu kauheen hyvältä, ku vanhemmat kiitteli jälkeenpäin siitä, että se meni ohi se kiusaaminen..."

”... nämä niin sanotusti vanhemmat, jotka eivät tiedä omaa tehtäväänsä... Et tuota semmonen on niinku miusta, se on niinku ikävää. Ja mie oon ainaki semmonen ollu, olen, että kyllä minnuu sitte hirveesti satuttaa ja valvottaa tämmöset vanhemmat, vanhemmat, jotka minun mielestäni väärällä tavalla. Ja sitte toinen on nämä lapset, joista kukaan ei pidä huolta. Ne on ne, mitkä niinku tuota mietityttää ja ovat niinku haaste ja yhä enenevissä määrin. 
(T: Eli heitä on enemmän ikäluokassaan?) On, on. Et jos lapsi sannoo, että meillä ei ollu jääkaapissa mitään niinku tänä aamuna viimeks. Ni mie lähetän keittolaan syömään... mee pyyä voileipä...”

Opettajan ja huoltajan kanssakäymisessä rakentunut pedagoginen hyvinvointi oli voimakkaasti värittynyt opettajan pedagogisen tehtävän kautta: jos opettaja koki saavansa tukea omaan pedagogiseen tehtäväänsä opettaja-huoltajavuorovaikutuksessa, hän koki sen jaksamista tukevaksi. Opettajat hahmottivat toimivan yhteistyön rakentamisen kotien kanssa tärkeäksi. Kuormittaviksi tekijöiksi opettajat kokivat opettaja-huoltajavuorovaikutuksessa kodin ja koulun hyvin erilaiset käsitykset lapsen koulukäynnin toimivista tukirakenteista, lapsen vaikeat kotiolot, kodin välinpitämättömyyden, haluttomuuden käsitellä mahdollisia ongelmia tai epärealistiset vaatimukset. Kuvatessaan ongelmallisia tilanteita opettajat myös pohtivat paljon oman työnsä mielekkäitä rajoja. Toisaalta opettajan ja huoltajien välinen toimiva yhteistyö ja positiivinen palaute koettiin sekä oppilaiden että oman jaksamisen kannalta tärkeäksi. Opettajat myös korostivat kodin ja koulun yhteistyössä jaettujen toimintaperiaatteiden merkitystä sekä oppilaiden että opettajien pedagogista hyvinvointia edistävänä tekijänä.

\section{Tulosten kokoavaa tarkastelua}

Kaikki opettajien kuormittumiseen ja jaksamiseen liittyvät primaarikontekstit liittyivät vuorovaikutukseen. Tulosten perusteella vaikuttaa siltä, että opettajan pedagogiseen hyvinvointiin vaikuttavat tekijät joko ovat nimenomaan vuorovaikutuksen elementtejä tai että vuorovaikutuskontekstien ulkopuoliset tekijät (esimerkiksi työhyvinvoinnin muut osa-alueet ja yhteiskunnalliset muutokset) heijastuvat opettajan pedagogiseen hyvinvointiin aina vuorovaikutuksen kautta.

Opettajalle yleisin jaksamisen ja kuormittumisen konteksti on oppilaan kanssa tapahtuva vuorovaikutus, erityisesti pedagogisesti vaativat ongelmatilanteet ja niiden ratkaisut. Kiinnostavaa on, että ongelmallinen, pedagogista tavoitetta haastava vuorovaikutustilanne ei itsestään selvästi kuormittanut opettajaa, vaan keskeistä oli, miten opettaja pystyi tilanteessa toimimaan eli millainen toimijuus hänelle mahdollistui. Samantyyppinen tilanne tai prosessi saattoi siis näyttäytyä sekä kuormittavana että jaksamista tukevana. Mielenkiintoista onkin tarkastella, mitkä tekijät säätelivät sitä miten opettaja sen koki. Kuormittumisen kuvauksille tyypillistä oli kaventunut toimijuus: omat toimintamahdollisuudet ja ratkaisukeinot koettiin syystä tai toisesta vähäisiksi.

Tyypillistä oli myös atomistinen toiminnan kohteen hahmottaminen, jolloin ongelmat eivät kytkeytyneet isompaan kokonaisuuteen. Kuormitusta lisäsi todennäköisesti atomistisuudesta seuraava epäanalyyttinen työote. Tällaisissa kuormittumistilanteissa opettajat kuvasivat myös voimattomuuden ja lamautumisen tunteita.

Atomistinen toiminnan kohteen määrittäminen ei kuitenkaan välttämättä sinänsä kuormita. Esimerkiksi opettajien pedagogisen kehittämisen vahva painottuminen omaan luokkahuoneeseen (atomistinen orientaatio jäsentää koulun pedagogisia prosesseja) voi hetkellisesti toimia jaksamista vai hyvinvointia tukevana tekijänä. Se kuitenkin tuottaa opettajan työhön pirstaleisuutta, jonka on todettu lisäävän kuormitusta.

Huomattavaa on, että opettajien kuvaamat kuormittavuustekijät ovat monisyisiä. Ne rakentuvat sekä koulun ulkopuolisissa yhteyksissä että koulun eri toimijoiden vuorovaikutussuhteissa. Kuormittavat tilanteet ovat siis luonteeltaan holistisia. Tällöin yksittäiseen asiaan, näkökulmaan, toimijaan tai tapahtumaan kiinnittyvät atomistiset ratkaisukeinot eivät edistä opettajan jaksamista ja oppilaiden ja opettajien pedagogisen hyvinvoinnin rakentumista.

Jaksamisen kuvauksille tyypillistä oli aktiivinen toimijuus. Tähän liittyi analyyttinen ja ennakoiva ongelmanratkaisu, jossa opettajalla oli ajattelun ja toiminnan välineitä haasteellisen tilanteen hoitamiseen. Myös holistinen työote oli jaksamista tukeville tilanteille tyypillinen toiminnan orientaatio. Kertoessaan jaksamisesta opettajat kuvasivat tilanteita, joissa hän hyödynsi ongelmanratkaisussaan koulupäivän kokonaisuutta ja myös koulun ulkopuolisia resursseja. Hän näki muut toimijat ympärillään - ja myös oppilaan ympärillä. Vaikuttaisikin siltä, että eräs opettajien pedagogisen hyvinvoinnin haaste on pystyä hahmottamaan pedagogisesti ja sosiaalisesti vaikeisiin tilanteisiin vaikuttavat tekijät riittävän monipuolisesti ja realistisesti ja siirtyä tarvittaessa atomistisesta holistisempaan toiminnan kohteen hahmottamiseen ja aktiiviseen orientaatioon. 


\section{Lopuksi}

Koulun arjessa on paljon tekijöitä, jotka kuormittavat opettajaa, mutta joihin opettaja ei voi omalla toiminnallaan juurikaan vaikuttaa. Sellainen on esimerkiksi uhka oman työpaikan menettämisestä koulujen lakkauttamisen vuoksi.

Kouluyhteisön hyvinvoinnin kehittämisen kannalta on olennaista pysähtyä pohtimaan, mihin jaksamisen ja kuormittumisen säätelijöihin opettajat voivat itse vaikuttaa ja miten näitä vaikutusmahdollisuuksia voisi tukea ja kehittää. Pedagogisen hyvinvoinnin prosessiksi voidaan kutsua kokonaisprosessia, jossa oppiminen ja hyvinvointi kietoutuvat yhteen pedagogisessa toiminnassa ja vuorovaikutuksessa. Pedagoginen toiminta ja vuorovaikutus ovat opettajan työn ydintä, ne ovat myös sellaista opettajan työn aluetta, johon opettajat yksilöinä ja yhteisöinä voivat hyvinkin paljon vaikuttaa. Tämän vuoksi ajatus pedagogisessa toiminnassa rakentuvasta hyvinvoinnista, joka voi jopa toimia vastavoimana muualla koettuun pahoinvointiin (esimerkiksi opettajien ja oppilaiden kotona koettuihin ongelmiin), saattaisi olla opettajille hyvinkin voimaannuttava. Tutkimuksen tulokset antavatkin viitteitä siitä, että oppimisen ja hyvinvoinnin yhteen kietoutumisen huomioiva pedagogiikka tukee opettajien jaksamista - ja vaikuttaa näin todennäköisesti myös oppilaiden hyvinvointiin ja oppimiseen.

Opettajan työn kannalta haasteen asettaa se, jos pedagogisen hyvinvoinnin primaarikontekstien välillä on epäjatkumoita, esimerkiksi jos ajatus oppilastyön ja opettajayhteisön kehittämisen linkittymisestä toisiinsa on useimmille opettajille jäsentymätön tai jopa vieras (ks. myös Savolainen 2001). Opettajien kuvaamat koulun arjen ongelmat edellyttävät holistista työotetta ja yhteisöllistä ongelmanratkaisua, samanaikaisesti opettajat eivät näytä mieltävän itseään opettajayhteisön aktiivisina toimijoina eivätkä rakenna ja hyödynnä opettajayhteisöä ratkaisun välineenä. Kyse saattaa olla myös tietoisesta oman autonomian suojelemisesta (Clement \& Vandenberghe 2000). Pedagogisen hyvinvoinnin kannalta opettajilla vaikuttaisikin olevan keskeistä paitsi vahvistaa omaa toimijuutta, myös määritellä se uudelleen; laajentaa ja rajata oma toimijuus mielekkäällä tavalla.

Tutkimuksen tulokset voidaan ymmärtää myös niin, että opettajat ilmaisevat opettajayhteisön vuorovaikutuksen olevan yleisen työhyvinvointinsa kannalta tärkeä, joko myönteinen tai kieltei- nen, suhteellisen pysyvä ja ennalta määräytyvä tekijä. Siinä ei kuitenkaan aktiivisesti rakenneta pedagogista hyvinvointia, vaan opettaja jää oman oppimisensa ja työnsä kehittämisen - rajaamisen ja laajentamisen - kanssa yksin luokkahuoneeseen. Tulos voidaan tulkita myös kollegiaalisuuden ja autonomian välisen jännitteen ilmentymänä, jossa opettaja valitsee kollegiaalisen yhteistyön sisällöt (esimerkiksi pelkästään kevyempien ja triviaalimpien asioiden käsittely) siten, että ne eivät uhkaa autonomiaa ja pääse kuormittamaan liikaa. Pelkkä ammatillisen vuorovaikutuksen lisääminen ei siis välttämättä tuota pedagogista hyvinvointia, jos sen sisältö ei ole mielekäs ja tue koulun ja opettajan ydintehtävää. Kouluyhteisöissä olisi tärkeää omaksua jaksamista tukevan kehittämistyön periaate: kaiken koulun kehittämisen tulee tukea perustehtävässä onnistumista, lapsen ja nuoren oppimisen ja kasvun mahdollistamista. Tällöin kehittäminen tukee sekä opettajan että oppilaan pedagogista hyvinvointia.

Pedagogisen hyvinvoinnin tukemisen näkökulmasta vaikuttaa siltä, että peruskoulun opettajien ammatillinen osaamisen kehittämisessä on oleellista keskittyä lähivuosina ihmissuhdeasiantuntijuuden vahvistamiseen sekä opettajien kollegiaalisuuden tukemiseen juuri tällä asiantuntijuuden alueella. Oppilas-opettajavuorovaikutuksen keskeisyys voitaisiin ottaa paremmin huomioon koulun työyhteisöjen kehittämistyössä ja opettajien täydennyskoulutuksessa. Se voisi olla kehittämisen ja jaksamista tukevan toiminnan lähtökohta.

Oppilas-opettajavuorovaikutuksen sisällä tapahtuvan pedagogisen toiminnan tukeminen yhteisöllisin ja kollegiaalisin keinoin voisi olla opettajayhteisöille omaksi koettu ja mielekäs yhteistoiminnan kehittämisen muoto. Aktiivisen toimijuuden laajentuminen ammatilliseen yhteisöön ja siellä käytävät yhteiset merkitysneuvottelut voisivat puolestaan tukea mielekästä oman työn rajaamista ja uusien toimintastrategioiden kehittymistä pedagogisiin kohtaamisiin, oppilas-opettajavuorovaikutukseen (Pyhältö ym. 2008). Pedagogisten prosessien holistisesta tarkastelusta tulisi näin yhteisötason toiminnan kohde ja opettajien välisen yhteistyön sisältö.

Pedagogisen hyvinvoinnin käsite voisi puolestaan auttaa tarkastelemaan opettajien työssä jaksamista ja ammatillista kehittämistä myönteisestä, opettajan toimijuutta tukevasta ja koulun perustehtävään sitoutuvasta näkökulmasta. 


\section{Lähteet}

Anderson, J., Reder, L. \& Simon, H. (1997). Situative versus cognitive perspectives: from versus substance. Educational Researcher 26 (1), 18-21.

Antonovsky, A. (1987). Unraveling the mystery: How people manage stress and stay well. San Francisco: Jossey-Bass.

Antonovsky, A. (1993). The structure and properties of the sense of coherence scale. Social Science Medicine 36 (6), 725-734.

Aunola, K. (2002). Motivaation kehitys ja merkitys kouluiässä. Teoksessa K. Salmela-Aro \& J-E. Nurmi (toim.) Mikä meitä liikuttaa. Modernin motivaatiopsykologian perusteet, 105-126.

Bakker, A. B., Demerouti, E., De Boer, E., \& Schaufeli, W. B. (2003). Job demands and job resources as predictors of absence duration and frequency. Journal of Vocational Behavior 62 (2), 341-356.

Bandura, A. (2001). Social cognitive theory: An Agentic perspective. Annual Review of Psychology 52, 1-26.

Boekaerts, M. (1993). Being concerned with wellbeing and with learning. Educational Psychologist 28 (2), 149-167.

Bowen, G.L., Richman, J.M., Brewster, A. \& Bowen, N. (1998). Sense of school coherence, perceptions of danger at school, and teacher support among youth at risk of school failure. Child and Adolescent Social Work Journal 15(4), 273-286.

Clement, M. \& Vandenberghe, R. (2000). Teachers' professional development: A solitary or collegial (ad)venture? Teaching and Teacher Education 16(1), 81-101.

Cobb, P. \& Bowers, J. (1999). Cognitive and situated learning perspectives in theory and practice. Educational Researcher 28(2), 4-15.

Deci, E.L. \& Ryan, R.M. (2002). Handbook of self-determination research. The University of Rochester Press.

Demerouti E, Bakker A B, Nachreiner F, Schaufeli W.B (2001). The job demands-resources model of burnout. Journal of Applied Psychology 86 (3), 499-512.

Geyer, S. (1997). Some conceptual considera- tions on the sense of coherence. Social Science \& Medicine 44 (12), 1771-1779.

Gordon, S.C., Dembo, M.H. \& Hocevar, D. (2007). Do teachers' own learning behaviors influence their classroom goal orientation and control ideology? Teaching and Teacher Education 23 (1), 36-46.

Hakanen, J. (2005). Työuupumuksesta työn imuun: Työhyvinvointitutkimuksen ytimessä ja reuna-alueilla. Helsinki: Työterveyslaitos.

Hakkarainen, K., Lonka, K. \& Lipponen, L. (2004). Tutkiva oppiminen. Järki, tunteet ja kulttuuri oppimisen sytyttäjinä. Helsinki: WSOY.

Helsing, D. (2007). Regarding uncertainty in teachers and teaching. Teaching and Teacher Education 23 (8), 1317-1333.

Huberman, A.M. \& Vandenberghe, R. (toim.) (1999). Understanding and preventing teacher burnout: A sourcebook of international research and practice. New York: Cambridge University Press.

Huusko, J. (1999). Opettajayhteisö koulun omaleimaisten vahvuuksien hahmottajana, käyttäjänä ja kehittäjänä. Joensuun yliopisto. Kasvatustieteellisiä julkaisuja 49.

Huusko, J., Pietarinen, J., Pyhältö, K. \& Soini, T. (2007). Yhtenäisyyttä rakentava peruskoulu - yhtenäisen perusopetuksen ehdot mahdollisuudet. Kasvatusalan tutkimuksia 34. Turku: Suomen kasvatustieteellinen seura.

Jahnukainen, M. (2001). Hyvä paha opettaja eli postmodernin nuorison kouluttamisen ongelma erityiskasvatuksen valossa. Nuorisotutkimus 19(4), 17-25.

Jokinen, K. (2001). Koulu neuvoteltavana. Nuorisotutkimus 19 (4), 3-16.

Jyrkämä, J. (2007). Toimijuus ja toimijatilanteet aineksia ikääntymisen arjen tutkimiseen. Teoksessa M. Seppänen, A. Karisto \& T. Kröger (toim.) Vanhuus ja sosiaalityö: sosiaalityö avuttomuuden ja toimijuuden välissä.

Karila, K., Alasuutari, M., Nummenmaa, AR., Korhonen, M., Rasku-Puttonen, H. Hännikäinen, M., Ikonen, M., Kronqvist, E. \& Korkeamäki R. (2006). Kasvatusvuorovaikutus. Tampere: Vastapaino.

Karvonen, S., Vikat, A. \& Rimpelä, M. (2005). The role of school context in the increase in young people's health complaints in Finland. 
Journal of Adolescence 28 (1), 1-16.

Kinnunen, U. \& Felt, T. (2005). Stressi työelämässä. Teoksessa U. Kinnunen, T. Feldt \& S. Mauno (toim.) Työ leipälajina. Työhyvinvoinnin psykologiset perusteet. Jyväskylä: PSkustannus.

Kinnunen, U. \& Hätinen, M. (2005). Työuupumus ja jaksaminen työelämässä. Teoksessa U. Kinnunen, T. Feldt \& S. Mauno (toim.) Työ leipälajina. Työhyvinvoinnin psykologiset perusteet. Jyväskylä: PS-kustannus.

Konu, A. \& Lintonen, T. (2005). Theory-based survey analysis of well-being in secondary schools in Finland. Health Promotion International 21, 27-36.

Konu, A.I., Lintonen, T.P. \& Autio, V.J. (2002). Evaluation of well-being in schools - a multilevel analysis of general subjective wellbeing. School Effectiveness and School Improvement 13 (2), 187-200.

Krapp, A. (2005). Basic needs and the development of interest and intrinsic motivational orientations, Learning and Instruction 15 (5), 381-395.

Kristersson, P. \& Öhlund, L.S. (2005). Swedish upper secondary school pupils' sense of coherence, coping resources and aggressiveness in relation to educational track and performance. Scandinavian Journal of Caring Science 19(1), 77-84.

Lahelma, E. (1992). Terveyssosiologia. WSOY.

Laine, K. (1997). Ameba pulpetissa. Koulun arkikulttuurin jännitteitä. Yhteiskuntatieteiden, valtio-opin ja filosofian julkaisuja 13. Jyväskylä: Jyväskylän yliopisto.

Lasten, nuorten ja perheiden hyvinvoinnin politiikkaohjelma, Suomen hallitus http:// www.vn.fi/toiminta/politiikkaohjelmat/fi.jsp.

Lazarus R.S. \& Lazarus, B.N. (1994). Passion and reason: making sense of our emotions. New York: Oxford University Press.

Lave, J. \& Wenger, E. (1991). Situated learning - Legitimate peripheral participation. Cambridge: Cambridge University Press.

Linnakylä (1993). Miten oppilaat viihtyvät peruskoulun yläasteella? Kouluelämän laadun kansallinen ja kansainvälinen arviointi. Teoksessa V. Brunel \& P. Kupari (toim.) Peruskoulu oppimisympäristönä. Peruskoulun arviointi 90-luvun tuloksia. Kasvatustieteiden tutki- muslaitos, Jyväskylä: Jyväskylän yliopisto.

Meriläinen M. \& Pietarinen J. (2007). Stress as a barrier to professional development. Teoksessa J. Löwstedt, P. Larsson, S. Karsten \& R. Van Dick (toim.) From intensified work to professional development. Berlin: P.I.E. Peter Lang, 111-128.

Miles, M.B. \& Huberman, A.M. (1994). Qualitative data analysis. An expanded sourcebook. $2^{\text {nd }}$ edition. Thousand Oaks: Sage

Morrison, I. \& Clift, S.M. (2005). Mental health promotion through supported further education. The value of Antonovsky's salutogenic model of health. Health Education 106 (5), 365-380.

Pallant, J.F. \& Lae, L. (2002). Sense of coherence, well-being, coping and personality factors: further evaluation of the sense of coherence scale. Personality and Individual Differences 33 (1), 39-48.

Pelletier, L.G., Legault, L. \& Séguin-Lévesque, C. (2002). Pressure from above and from below as determinants of teachers' motivation and teaching behaviours. Journal of Educational Psychology 94 (1), 186-196.

Pietarinen, J. (2000). Transfer to and study at secondary school in Finnish school culture: Developing school on the basis of pupils' experiences. International Journal of Educational Research 33 (4), 383-400.

Pietarinen, J., Soini, T. Pyhältö, K. \& Huusko, J. (2007). Esitelmä: Pedagoginen hyvinvointi kouluyhteisön haasteena. Kasvatustieteen päivät, Vaasa.

Pyhältö, K. (2003). Pragmatistiskonstruktivistinen näkökulma opettajuuteen. Uusi opettajuus? Kasvatuspsykologian tutkimusyksikkö. Tutkimuksia 1/2003. Helsingin yliopisto.

Pyhältö, K. \& Soini, T. 2007. Opetussuunnitelma koulun kehittämisen välineenä. Teoksessa P. Johnson (toim.) Suuntana yhtenäinen perusopetus. Jyväskylä: PS-kustannus.

Pyhältö, K., Pietarinen, J. Soini, T. \& Huusko, J. (2008). Luokan-, aineen- ja erityisopettajat yhtenäisen perusopetuksen rakentajina. Kasvatus 39 (3), 218-134.

Rauste-von Wright, M., von Wright, J. \& Soini, T. (2003) Oppiminen ja koulutus. WSOY.

Rauste-von Wright, M., Soini, T., Pyhältö, K., Eerola, S., Pyhälä, S. \& Rämä, I. (2003). Koulun 
eksperttiys. Tutkimus yhtenäisen peruskoulun toteutumisen ehdoista. Helsingin kaupungin opetusviraston julkaisusarja A1: 2003.

Rudolf, K.D., Lambert, S.F., Clark, G.C. \& Kurlakowsky, K.D. (2001). Negotiating the transition to middle school: the role of self-regulatory processes. Child Development 72, 929-946.

Ryan, R.M. \& Deci, E.L. (2000). Self-determination theory and the facilitation of intrinsic motivation, social development, and well-being. American Psychologist 55, 68-78.

Ryan, R.M. \& Deci, E.L. (2001). Intrinsic and extrinsic motivations: Classic definitions and new directions. Contemporary Educational Psychology 25, 68-81.

Salomon, G. \& Perkins D. (1998). Individual and social aspects of learning. Review of research in education 23 (1), 1-24.

Savolainen, A. (2001). Koulu työpaikkana. Työolojen itsearviointi ja kehittämistarpeet oppilaiden ja henkilöstön näkökulmasta. Väitöskirja. Acta Universitatis Tamperensis 830.

Sawyer K. (toim.) (2005). Cambridge handbook in the learning sciences. New York: Cambridge University Press.

Schaufeli W.B. \& Bakker A.B. (2004). Job demands, job resources, and their relationship with burnout and engagement: a multi-sample study. Journal of Organizational Behavior 25 (3), 293-315.

Seligman M E P, Csikszentmihalyi M. (2000). Positive psychology. An introduction. American Psychologist 55 (1), 5-14.

Sheldon K M, King L. (2001). Why positive psychology is necessary. American Psychologist 56 (3), 216-217.

Silins, H. \& Mulford, B. (2002). Schools as learning organisations. The case for system, teacher and student learning. Journal of Educational Administration 40 (3-4), 425-446.

Smylie, M.A. (1999). Teachers' stress in time of reforms. Teoksessa Huberman, A.M. Vandenberghe, R. (toim.) (1999). Understanding and preventing teacher burnout: A sourcebook of international research and practice. New York: Cambridge University Press.

Soini, T. (1999). Preconditions for active transfer in learning processes. Commentationes Scientiarum Socialium 55. Helsinki: The Finnish society of sciences and letters.
Sonnentag, S. \& Frese, M. (2003). Stress in organizations. Teoksessa Borman, W.C., Ilgen, D.R., Klimoski, R.J. (toim.), Handbook of Psychology, vol. 12: Industrial and organizational psychology, New York: Wiley, 453-491.

Syrjäläinen., E. (2002). Eikö opettaja saisi jo opettaa? : Koulun kehittämisen paradoksi ja opettajan työuupumus. Tampereen yliopisto.

Tarter, C.J. \& Hoy, W.K. (2004) A systems approach to quality in elementary schools. A theoretical and empirical analysis. Journal of Educational Administration 42 (5), 539-554.

Thuneberg, H. (2007). Is a majority enough? Psychological well-being and its relation to academic and prosocial motivation, self-regulation and achievement at school. Akateeminen väitöskirja, Helsingin yliopisto: Käyttäytymistieteiden tiedekunta.

Torsheim, T., Aarø, L.E. \& Wold, B. (2001). Sense of coherence and school-related stress as predictors of subjective health complaints in early adolescence: Interactive, indirect or direct relationships. Social Science and Medicine 53 (5), 603-614.

Vanhalakka-Ruoho, M. (2005). Kohtuullisen hyvä kylä... mielenrakentaminen kehittämisprojektissa. Kasvatustieteiden tiedekunnan tutkimuksia 96. Joensuu: Joensuun yliopisto.

Van Houtte, M. (2006). Tracking and teacher satisfaction: Role of study culture and trust. The Journal of Educational Research 99 (4), 247-254.

Weick, K.E. (1976). Educational organizations as loosely coupled systems. Administrative Science Quarterly 21, 1-19. Uudelleenjulkaistu 1988 teoksessa A. Westoby (toim.) Culture and power in educational organizations. Milton Keynes: Open University Press, 56-73.

Välijärvi, J., Kupari, P., Linnakylä, P., Reinikainen, P., Sulkunen, S., Törnroos, J. \& Arffman, I. (2007). The Finnish succes in PISA - and some reasons behind it 2. Koulutuksen tutkimuslaitoksen PISA-julkaisuja. Jyväskylä: Jyväskylän yliopisto.

Yin, R.K. (1994). Case study research. Design and methods. $2^{\text {nd }}$ edition. Thousand Oaks: Sage. 